\title{
INCLUSIONARY HOUSING IN SMALL TOWNS AND RURAL PLACES: THE CALIFORNIA EXPERIENCE
}

\author{
Robert J. Wiener \\ California Coalition for Rural Housing \\ Dewey K. Bandy \\ Coalition for Rural Housing
}

Remisión Artículo: 2-10-2007

Palabras Clave: Affordable housing programes; inclusionary housing; California

Resumen: Across California, and many other parts of the U.S., cities and counties of all sizes urban, suburban, and rural - are responding to severe shortages of affordable housing via adoption of inclusionary housing $(\mathrm{IH})$ programs. Also known as inclusionary zoning, $\mathrm{IH}$ programs encompass a large variety of policies that share the common element of requiring or encouraging private developers of housing to directly build or facilitate the building of affordable housing for purchase or rent in new single-family home subdivisions and apartment complexes. No two programs are identical.

\section{Introduction}

Since the earliest programs were adopted in Fairfax County, Virginia, Montgomery County, Maryland, and Petaluma, California, in the early 1970s, IH has proven to be an effective tool for local jurisdictions to ensure that new housing development is balanced with affordable dwellings for lower-income households. Most programs define "affordable" as a payment that does not consume more than $30 \%$ of a household's gross monthly income and target households with incomes below the area median income (AMI) adjusted for household size. Some programs also target assistance to households with incomes above the AMI, especially first-time homebuyers unable to purchase conventional homes in expensive residential markets.

Oftentimes, these programs offer private developers alternatives to building the below-market rate homes themselves on the same site as the market-rate homes. These include options to: 1) partner with a nonprofit organization that agrees to build the units; 2 ) build the units off-site or convert or rehabilitate existing units under certain conditions; 3 ) dedicate land to the local government that will accommodate a comparable number of units; 4) pay an "in-lieu" fee to the local government to be used for affordable housing; or 5) build more than the required units in exchange for a reduced requirement in another development. Programs may also include financial offsets, such as direct subsidies, density bonuses, design and parking concessions, fee waivers or deferrals, and expedited processing, that reduces developer costs of building the below-market-rate units.

Nowhere has the growth of these programs been more widespread and more impactful than in California. Since its inception in the City of Palo Alto in 1973 through mid-2006, at least 170 cities and counties in the state had formally adopted an $\mathrm{IH}$ program through an ordinance or policy - nearly one-third (31.8\%) of the state's 536 jurisdictions (NPH/CCRH: 2007). In 1994, a 
study by the California Coalition for Rural Housing revealed 64 jurisdictions with $\mathrm{IH}^{1}{ }^{1}$ In 2003, a study by the California Coalition for Rural Housing and the Nonprofit Housing Association of Northern California revealed an additional 43 jurisdictions. ${ }^{2}$ Thus, in the span of about 12 years the number of known programs has grown by 265\%. It is estimated that since 1999 these programs have resulted in nearly 29,300 new affordable homes. ${ }^{3}$

The largest cluster of $\mathrm{IH}$ programs is in the nine coastal counties comprising the greater San Francisco Bay Area with another, smaller cluster in the southern coastal counties stretching from Los Angeles south to San Diego (Exhibit 1). These programs account for over half of all programs, $37.1 \%$ and $14.7 \%$ respectively. A third cluster can be found in the Sacramento metropolitan area, which accounts for $5.9 \%$ of all programs. ${ }^{4}$ In California, most IH programs are located in census-designated metropolitan counties; but, then again, most counties in the state are metropolitan counties, even those with large areas of open space, low-density population, and high dependence on agriculture and other rural-based economic activity.

Within the academic and professional literature, many have written in recent years about the expansion and implications of inclusionary housing (Calavita: 2006) A significant volume of this literature has been sponsored or commissioned by national organizations with an interest in land use policy, affordable housing, planning, and social equity. These include: U.S. Department of Housing and Urban Development (Abt Associates: 2006); Urban Land Institute (Porter: 2004); American Planning Association (Brunick: 2004); National Housing Conference (2004): Policy Link (2003, 2004); and Business and Professional People for the Public Interest (Anderson: 2003; Brunick: 2004).

A singular characteristic of the literature is its focus on $\mathrm{IH}$ in major population centers - cities and metropolitan counties. A recent issue of the American Planning Association's publication Zoning Practice highlighted the adoption or expansion of $\mathrm{IH}$ in a number of larger cities, such as Denver, Boston, San Francisco, San Diego, and Sacramento, since the early 1990s (Brunick: 2004). Other publications have addressed the potential adoption of programs in Washington, D.C., and New York City (Policy Link: 2003, 2004).

Much less has been made of the 30-year experience of this strategy in small- and mediumsized jurisdictions. In practice, $\mathrm{IH}$ has been, and continues to be, a phenomenon largely found in suburban communities and in a significant and expanding number of small towns and rural places not associated with large conurbations. Only a handful of major central cities of large metropolitan areas have adopted these programs, nationwide. No studies have plumbed deeply into the functioning of these programs in smaller jurisdictions - their productivity, innovations, and adaptations.

In mid-2006, nearly one-third (54) of inclusionary housing programs in California were located in cities and counties with population under 20,000 and nearly 60 percent (100) were in localities with fewer than 50,000 people (based on 2005 population estimates). ${ }^{5}$ In the 1970 s and 1980 s the overwhelming majority of programs could be found in coastal counties. In the 1990s and

\footnotetext{
${ }^{1}$ California Coalition for Rural Housing. 1994. Creating Affordable Communities: Inclusionary Housing Programs in California. Sacramento, CA.

${ }_{2}^{2}$ California Coalition for Rural Housing and Nonprofit Housing Association of Northern California. 2003. Inclusionary Housing in California: 30 Years of Innovation. Sacramento and San Francisco, CA.

${ }^{3}$ Nonprofit Housing Association of Northern California, California Coalition for Rural Housing, San Diego Housing Federation, and Sacramento Housing Alliance. 2007. Affordable by Choice: Trends in California Inclusionary Housing Programs, p. 5. San Francisco, CA.

4 The nine San Francisco Bay Area counties are San Francisco, Marin, Sonoma, Napa, Solano, Contra Costa, Alameda, Santa Clara, and San Mateo. The southern coastal counties are Los Angeles, Orange, and San Diego. The Sacramento metropolitan counties are Sacramento, Yolo, Sutter, Yuba, Placer, and El Dorado.

${ }^{5}$ California Department of Finance. 2007. E-4 Population Estimates for Cities, Counties and State, 2001-2007. Sacramento, CA.
} 
2000s, the direction of growth has increasingly been outside the built-up coastal salient where they first took root. Increasingly, small- and medium-sized jurisdictions in agricultural areas, in the interior of the state, and in rural tourist, resort, and retirement destinations - the new magnets of population growth - are adopting IH programs.

This paper will analyze the findings of several recent studies that evaluate the growth and effects of inclusionary housing programs in California. After discussing the main arguments for and against $\mathrm{IH}$, we examine the characteristics of programs in jurisdictions with population under 20,000, case-study four of these jurisdictions, and explore the opportunities and barriers to design, adoption, and implementation of such programs in small towns and rural places.

\section{The Inclusionary Housing Debate: Myth and Reality}

As the inclusionary housing tool is increasingly employed by more and more jurisdictions in California it becomes correspondingly important to draw on lessons from its applications for two reasons. First, the long history of $\mathrm{IH}$ and widespread application provide a rich body of experience and lessons for jurisdictions to consider when crafting, updating, and implementing such programs. To harvest these lessons requires examination and analysis of the specific experiences, accomplishments, and problems of individual jurisdictions that have already implemented IH programs.

Second, although proven to be effective, inclusionary housing has also proven to be controversial. $\quad \mathrm{IH}$ is bitterly opposed by much of the building and real estate industries (Reason Foundation: 2004). Many of these criticisms have been refuted by IH proponents. However, the ultimate response to criticisms of $\mathrm{IH}$ must come from the actual implementation experience of jurisdictions that are utilizing it.

Most advocates of inclusionary housing would subscribe to the belief, as characterized by Marcuse (1986), in a benevolent state that can be a positive agent for obtainment of social equity. $\mathrm{IH}$, therefore, is an appropriate tool for society through governmental action to achieve a greater supply and more equitable distribution of housing for lower-income people as communities grow. IH programs seek to achieve at least the following three goals:

Increased Production: Production of affordable housing in California, as in many other parts of the country, is very expensive due to the high costs of labor, materials, financing, local fees, and above all land. IH deals principally with the land component. It ensures that new growth areas will include new affordable housing. It ensures availability of scarce land, especially in jurisdictions that are mostly built-out or where land is monopolized by a handful of profitmotivated owners specializing in the "luxury" housing market. Some economists have argued that the imposition of $\mathrm{IH}$ requirements in jurisdictions reduces land costs - an imputed subsidy benefiting future affordable housing development. Given the past several decades of deep cuts in federal and state housing subsidies and intense competition for existing funding and land, IH shifts some of the costs of affordable housing production to the private sector and frees up land that would not otherwise be available or affordable.

Social and Economic Integration: A critical element of inclusionary housing that distinguishes it from other affordable housing strategies is its capacity to actually achieve social and economic integration. Not only does IH address the shortage of affordable housing, but where programs are working to maximum advantage they are providing real opportunities for working families to live in new-growth areas with high-quality schools, shopping, parks, and other services. In most cases, units are being built within newly developing areas in choice locations, contiguous to and indistinguishable from market-rate units. Working families are living side-by-side with middle-income families. Instead of concentrating low-income households in housing in distressed areas, $\mathrm{IH}$ distributes affordable housing throughout new market areas. 
Simultaneity: A third, and less discussed, goal of inclusionary housing is simultaneity, meaning that the affordable units are built generally at the same time as the market-rate units. The great advantage of concurrent development is that it helps overcome one of the major obstacles to affordable housing production - opposition from existing neighbors, the so-called Not-In-MyBack-Yard (NIMBY) response. Organized neighborhood opposition adds additional, costly delays and can kill projects. Simultaneity can preempt local resistance.

Proponents, however, are often quick to note the shortcomings of inclusionary housing. $\quad \mathrm{IH}$ is not a panacea. First, IH only works in jurisdictions that are growing and is wholly dependent on the vicissitudes and volatility of the residential construction industry. It does not address the housing problems of areas that are not growing.

Second, IH is only one tool, and perhaps a minor one at that, in an arsenal of local strategies that can be deployed by local governments. The most successful jurisdictions are those that create mandatory programs with incentives that directly result in new units. Jurisdictions with voluntary programs, mandatory programs with weak alternatives to direct development by market-rate developers, and mandatory programs that impose onerous conditions on developers and offer few if any financial or regulatory offsets usually fail to achieve the purported goals of the program. Jurisdictions that impose $\mathrm{IH}$ requirements on market-rate developers but deny or hinder housing production by affordable housing developers defeat the purpose of an IH program, which is to supplement not replace other production methods.

Third, administering these programs and ensuring compliance with affordability covenants can be labor-intensive and requires systematic and long-term monitoring. In smaller, lower-capacity jurisdictions, lack of professional staff and oversight can undermine the positive impacts of a well-intentioned program.

Opponents of inclusionary housing, primarily from the building and real estate industries, invoke the traditional arguments that government meddling in the private market is inherently inefficient and ineffective. Redistributive policies that seek to recapture, reallocate, and redirect economic gains realized by free market risk-takers and actors to lower-income people result in inadvertent, deleterious consequences that cause more harm than good. Their principal objections to $\mathrm{IH}$ are:

Taxes one group to benefit another: Inclusionary housing is unfair because it places the financial burden of providing affordable housing for low-income households squarely on the shoulders of one industry. Why should builders have to pay for a societal need caused by exogenous factors, such as low household incomes, attributable to a host of causes over which builders have no control? Other industries are not asked to forego profits to house lower-wage workers.

Reduces overall housing production: Inclusionary housing requirements hurt lower-income households because residential developers will curtail development activity or opt not to develop at all in $\mathrm{IH}$ jurisdictions and, instead, take their business to non- $\mathrm{IH}$ jurisdictions. This will have the effect of decreasing the overall supply of new housing, increasing the prices of existing homes, reducing residential mobility and the normal filtering of lower-cost housing to lower-income households, and further pricing these households out of the market. The small number of $\mathrm{IH}$ units produced in local jurisdictions does not compensate for the reduced numbers in overall housing production resulting from the chilly environment created by $\mathrm{lH}$.

Instead, builders maintain that shortages in supplies of affordable housing are due to too much government intervention in the private market - overbearing land use and environmental rules that restrict what can be built and where, excessive local government fees, and bureaucratic 
delays in development approvals. With adequate land supplies, reductions in local fees, and development certainty, the private market can meet the housing needs of most households.

Shifts costs to middle-income families: Imposition of inclusionary requirements forces residential developers to shift costs to middle-income homebuyers and renters in the form of higher purchase prices and rents. Load-shifting costs from one group of consumers to another is unfair and creates financial burdens for the middle-class, which does not benefit from direct government housing subsidies. In some cases, developers will accommodate by changing their product types to provide higher-end housing for higher-income households than they would have absent the presence of an IH program.

Lowers Property Tax Revenues: Local governments will realize lower property tax collections from below-market-rate housing and its depressive effect on the values of nearby market-rate housing. This will mean less revenue for critical public services at a time when local governments are starved for revenue and favoring "big-box" commercial developments with greater tax-generation potential and fewer service demands.

Exports Inner City Problems: Inclusionary housing is social engineering. Higher-density, lowcost housing will cause the replication of inner city slums in new neighborhoods, resulting in an influx of poor (minority) families, traffic congestion, crowded schools, high service demands, crime, and other attendant social problems. Recurrent is an underlying theme of self-reliance a "bootstrap" iconography - that says IH benefits the undeserving poor while hard-working people have to depend on their own resources to obtain decent and affordable housing.

These claims are challenged by inclusionary housing advocates, citing methodological flaws in industry-commissioned research, studies showing the positive impacts of $\mathrm{IH}$, and the experiences of local jurisdictions (Basolo and Calavita: 2004; Rusk: 2005).

With respect to the developer "tax" imposed by $\mathrm{IH}$, proponents counter that development is a privilege not a right and developers should share in the social costs of new development. Requirements that developers contribute to the provision of affordable housing are little different from requirements that developers dedicate land or pay fees to satisfy communities' needs for schools, parks, and other public services. The concept of "nexus" or "linkage" is becoming increasingly enshrined in local land use laws to require commercial interests that contribute to increased housing demand and consume scarce land to help local governments meet the community's current and future needs for affordable housing.

Regarding the impacts of $\mathrm{IH}$ on overall production, longitudinal studies of permitting activity in $\mathrm{IH}$ jurisdictions indicate that construction activity does not decrease as a direct result of the adoption of an inclusionary housing program and, in fact, has experienced healthy increases in some jurisdictions (Rosen: 2004). Where construction activity has decreased, the change is much better explained by national downturns in the construction economy caused by such extra-local factors as higher interest rates or by local conditions, such as dwindling supplies of land or anti-growth movements. An analysis by Rosen of 28 cities in California with and without $\mathrm{IH}$ found that production decreases correlated much more closely with locally high unemployment rates than they did with adoption of an $\mathrm{IH}$ program.

Finally, the claim that the costs of inclusionary housing are shifted to market-rate renters and buyers is counter-intuitive. If there is additional and unrealized elasticity in the willingness and ability of buyers and renters to pay higher prices, why aren't developers charging the highest prices they can command in the market? In the absence of an IH program, would developers voluntarily lower prices? Developers can only pass on as much cost as consumers are willing and able to pay. In practice, developers are not building $\$ 400,000$ homes and selling them for $\$ 200,000$; they're building $\$ 200,000$ starter homes and selling them for $\$ 200,000$. 
Arguably, the question of who pays is still an open question that has not been proven with absolute certitude by either proponents or opponents. Generally, economists agree that developers do not bear the entire cost of an inclusionary requirement and share this with landowners (Rosen: 2004; Nelson and Moody: 2003). Over time, the cost of the requirement will figure into reduced land prices that developers can negotiate with landowners. Where developers may incur the greatest cost is where they own land purchased at peak prices prior to the adoption of an IH program. To determine conclusively whether or not market-rate consumers ultimately experience some of the cost, close inspection of developer pro formas for specific developments is needed to fully understand how the production of below-market rate units factors into overall development costs and profitability.

\section{Methodology}

In 1994, the California Coalition for Rural Housing (CCRH) conducted the first statewide survey to assess the prevalence of inclusionary housing programs in the state. That survey revealed that 64 jurisdictions (12\% of jurisdictions, statewide) had adopted IH programs.

$\mathrm{CCRH}$ and the Nonprofit Housing Association of Northern California (NPH) performed a followup survey in 2002 and 2003 to track the increasing use of this tool, as well as to learn more about the major policy decisions related to implementing effective $\mathrm{IH}$ programs throughout California. The survey found that 107 jurisdictions had local IH programs. The survey estimated that these policies had contributed at least 34,000 affordable units to the state's housing stock since the first programs were adopted in the 1970s. Although the survey collected overall housing production figures, it generated interest in more precise data addressing not only the total number of units, but the type, tenure, and affordability targets of the units produced.

Consequently, in 2006, CCRH, NPH, the San Diego Housing Federation, and Sacramento Housing Alliance sponsored a study of local jurisdictions to determine the growth in programs statewide and provide a more detailed snapshot of the affordable housing that is being produced by these programs. A brief online survey was distributed to every city and county with the assistance of the League of California Cities to ascertain whether jurisdictions had adopted an $\mathrm{IH}$ program. An inclusionary housing program was defined as a formal ordinance or policy adopted by the local jurisdiction which imposes a mandatory requirement or voluntary goal to reserve a certain percentage of housing units for lower-income households within each new residential development. The response rate was nearly $80 \%$ (424 jurisdictions).

A follow-up "production survey" was then forwarded to each of the 169 jurisdictions that responded affirmatively to the initial survey (Note: Another jurisdiction adopted an IH program following the initial study, increasing the total jurisdictions with $\mathrm{IH}$ to 170.) The survey sought production data for the period 1999 through mid-2006, including the total number of residential permits issued and the number of permits issued for inclusionary units. Inclusionary units permitted were further disaggregated by income band (percentage of AMI targeted), whether the units were for rent or purchase, and whether the units were built on-site by the market-rate developer, on-site in partnership with a nonprofit or local government, or off-site by the developer or another entity. Ninety-one jurisdictions responded (54\% response rate); 71 reported at least one unit and 20 , primarily recently adopted programs, reported no units permitted.

Production questions were difficult for some jurisdictions to answer because these numbers are tracked by different city or county departments or not at all. There is no uniform system of tracking production of inclusionary units, statewide. For jurisdictions not reporting total 
numbers of residential permits issued, permit data were used from the Construction Industry Research Board of the California Building Industry Association. ${ }^{6}$

In addition to these surveys, $\mathrm{CCRH}$ independently assembled electronic and hard copies of the $\mathrm{IH}$ ordinances and policies of 134 of the 170 jurisdictions. Over 30 key characteristics of these programs were input into a searchable database available at www.calruralhousing.org. This paper draws from the production survey and summary information in the database to profile the characteristics of $\mathrm{IH}$ programs in small towns and rural places with populations under 20,000 and compares them to larger jurisdictions with populations over 20,000 .

Finally, CCRH examined four case-study cities to evaluate the effectiveness of inclusionary housing in small towns and rural places. The communities studied were selected because they are representative of the trends in the growth of $\mathrm{IH}$. Interviews were conducted with key staff of local governments and affordable housing developers, supplemented by a review of existing documents and data.

\section{Key Characteristics of IH Programs in Small Towns and Rural Places}

To reach beyond the emotion and the claims, it is necessary to evaluate each $\mathrm{IH}$ program individually to ascertain its strengths and weaknesses and separate myth from reality. In this section, and the section that follows, we profile the major characteristics of IH programs in small towns and rural places of less than 20,000 population in 2005 and evaluate the experiences in four case-study communities. We then examine the question of why small- and medium-sized jurisdictions decide to adopt inclusionary housing in surprising numbers and what lessons can be learned from current practice and experience

Small-town/rural programs account for a significant percentage of all programs. One of the most astonishing findings is that small towns and rural places account for almost one-third (31.8\%) of all jurisdictions in California with IH programs (54 of 170 jurisdictions). Chart 1 shows that if one includes jurisdictions with populations between 20,000 and 50,000 , nearly six of every $10(58.9 \%)$ programs can be found in smaller communities. Of course, there are more jurisdictions within these population ranges than, for example, in the 500,000 and above range. But, nonetheless, these figures defy the conventional wisdom that $\mathrm{IH}$ is overwhelming an urban and metropolitan response. Moreover, the percentages of jurisdictions with $\mathrm{IH}$ within these population ranges compare with the percentages of all jurisdictions within these ranges. Statewide, $37.3 \%$ (200 of 536) of jurisdictions have populations under 20,000 compared to $31.8 \%$ of inclusionary jurisdictions; $24.1 \%$ (128 of 536) have populations between 20,000 and 50,000 compared to $27.1 \%$ of inclusionary jurisdictions.

The number of $\mathrm{IH}$ programs is growing dramatically. Years of program adoption were available for 143 of the 170 programs, statewide. Chart 2 indicates that the great majority of $\mathrm{IH}$ programs (86.4\%) in jurisdictions with current population below 20,000 were adopted since 1990. The decade of the 2000s accounts for over half of these programs to date and, at the current rate of growth, will likely account for a significant majority by decade's end. Among larger jurisdictions, nearly three-quarters (73.7\%) of programs were adopted since 1990 and over one-third (34.3\%) in the 2000s. The 1990s and the first half of the 2000 s coincide with periods of sustained and huge population growth when California averaged 500,000 new residents annually. The fastest-growing areas are in interior suburbs and more rural parts of the state. This period also coincides with historically low levels of housing affordability affecting record numbers of homebuyers and renters.

\footnotetext{
${ }^{6}$ See http://www.cirbdata.com.
} 
The great majority of programs are mandatory. About $86 \%$ of all small-town/rural jurisdictions mandate that developers meet inclusionary housing requirements, rather than provide incentives for voluntary compliance. Chart 3 suggests that these jurisdictions are somewhat less likely than larger jurisdictions to impose such mandates. This can be explained by the conservative and cautious political culture of many smaller jurisdictions. It may also reflect a judgment and concern that mandates in communities with limited numbers of developers and where certain types of development are infrequent, such as rental housing, will only scare away future development. Better to negotiate the inclusion of affordable housing on a project-byproject basis using "carrots" rather than "sticks".

Most programs are codified by ordinance. Nearly three-quarters (71.4\%) of jurisdictions adopted their inclusionary programs in the form of an ordinance. Fewer then $10 \%$ are based solely on a policy statement in the Housing Element of their General Plan. Revealingly, there is a significant difference in the percentages of small-town/rural jurisdictions that operationalize their programs through their zoning codes compared to larger jurisdictions. As Chart 4 demonstrates, over one-third (38.0\%) of larger jurisdictions impose inclusionary requirements through zoning laws, rather than a separate IH law, and about one-fifth $(21.4 \%)$ of smaller jurisdictions. Generally, the larger the jurisdiction the more likely it is to have sophisticated and complex zoning laws, such as affordable housing overlays, compared to smaller jurisdictions, which typically have a limited number of zoning designations.

Most programs are triggered by developments of $2-5$ units. In over half $(52.4 \%)$ of the programs in small towns and rural places, both for rent and ownership, inclusionary requirements are triggered when developers propose multiple-unit developments with minimums of at least two to five units. It can be seen in Charts 5 and 6 that this contrasts with programs in larger jurisdictions, which are generally triggered by larger-size developments. This can be explained as an issue of scale. Multiple-unit developments are larger and more common as jurisdictions increase in population; thus, these jurisdictions are less likely to look to smaller developments to meet their affordable housing needs. In smaller developments, when the number of affordable units as a percentage of total units equates to a fractional unit (less than one), developers may be required to instead pay a fee to the local government in lieu of construction. In more than a quarter of all jurisdictions the inclusionary requirement is triggered by developments of any size.

Rental units tend to be targeted towards low- and very low-income households. The overwhelming majority of inclusionary programs target both renters and homebuyers. Over $90 \%$ percent of small-town/rural jurisdictions target low-income renter households (incomes between $51-80 \%$ of area median income (AMI)). Over $85 \%$ target very low-income households (incomes between 31-50\% of AMI). Moderate-income households (incomes between $81-120 \%$ of $\mathrm{AMI}$ ) are less likely to be beneficiaries of rental housing programs, but still over $60 \%$ target this group. Chart 7 shows that there is little difference between smaller and larger jurisdictions.

Small-town/rural programs also target very low-income homebuyers. Over $90 \%$ of smalltown/rural programs target low-income homebuyers. This compares with the percentage of larger jurisdictions that target low-income homebuyers. The differences are most pronounced in targeting for very low- and moderate-income homebuyers. According to Chart 8, smaller jurisdictions are more likely than larger jurisdictions (81.6\% to $65.2 \%)$ to target homebuyers with very low incomes. This is due to the fact that the gap between incomes and home purchase prices may be narrower in some smaller jurisdictions; thus, the price reduction and subsidy needed to lift very low-income households into homeownership is less. Conversely, larger jurisdictions are more likely to target moderate-income households because the economics of homeownership for this group are more feasible than for the very low-income group. 
Nearly half of programs require that at least $6-10 \%$ of new units be affordable. Most commonly, small towns and rural places mandate that $6-10 \%$ of new units for rent and ownership, $47.2 \%$ and $45.7 \%$ respectively, be affordable to targeted income groups. About one-third requires that $11-15 \%$ of new units be affordable; just over $10 \%$ requires that $16-20 \%$ of units be affordable. As indicated in Charts 9 and 10, these percentages track with the trends seen in larger jurisdictions.

Small towns and rural places offer a range of construction alternatives. As in larger jurisdictions, the programs of small towns and rural places typically allow a menu of alternatives to on-site construction directly by market-rate developers. Chart 11 indicates that the most common alternative is payment of an in-lieu fee (83.3\%), followed by off-site construction (55.6\%), and land dedications and conversion to affordable housing (44.4\% each). What appears evident, however, is that larger jurisdictions are somewhat more likely to offer a range of alternatives, especially the credit transfer alternative. This can be attributed to the generally more sophisticated and complex nature of the programs in larger jurisdictions and the efforts by some smaller jurisdictions to limit alternatives in order to simplify administration and avoid alternatives that will place them in the role of developer.

Small towns and rural places offer a range of developer incentives. Finally, smaller jurisdictions, like larger jurisdictions, offer a diverse set of incentives to help offset developer costs of producing the below-market-rate units. The most common incentive listed in over three-fourths (77.4\%) of programs is a density bonus - an increase in the allowable density. Whether or not jurisdictions actually offer bonuses in practice or developers choose to use them is an unanswered question. Some rural developers claim that the density bonus has little value in low-density localities because of constraining topography, infrastructure limitations, and neighborhood opposition. On the other hand, fee deferrals, reductions, and waivers are concessions that small local governments do have control over and can usually grant on a discretionary basis without public approval. Chart 12 suggests that jurisdictions of fewer than 20,000 people are somewhat more likely to offer these incentives. It is unclear, however, why a higher percentage of small-town and rural programs offer the prospect of additional subsidy when these communities are typically starved for financial resources.

\section{Lessons from the Field}

\section{Mammoth Lakes: Innovation Overcomes Rural Barriers}

Rural tourist, resort, and retirement communities may face a number of special challenges when it comes to affordable housing. Such communities are often isolated, have limited resources, and lack the capacity of larger, more urban jurisdictions. Their economic base is largely based on recreational and seasonal activities. Much of the employment in these sectors is service, seasonal, and low-wage. Local housing costs are often driven by the high-end luxury and vacation home market, leaving local workers and residents priced out. Topography, lack of infrastructure, limited building seasons, extreme weather, and environmental constraints conspire to further drive housing costs upward. Opponents often cite these conditions as reasons why inclusionary housing will never work.

Yet, one remarkable community is making inclusionary housing work despite the presence of all these obstacles. Mammoth Lakes, a small rural incorporated town of just over 7,000 citizens, has employed an entrepreneurial

\section{Quick Facts}

Population: 7,093

Location: Mono County

Year Inclusionary Adopted: 2000

Inclusionary Requirements: Comprehensive approach that requires all development to create housing for the employees that will be generated by the type of development. Housing production requirements are based on the size and type of development. Income levels targeted range from very low-income (50\% of area median income (AMI)) up to $200 \%$ of AMI.

Alternatives to Construction: In-lieu fees, land dedications, partnerships with nonprofit developers

Number of Affordable Units Produced: 200

Lessons Learned: Comprehensive affordable housing requirements equitably spread burden across all development. Support for local development capacity provides the basis for a proactive and entrepreneurial approach to inclusionary housing. This approach allows land dedications and in-lieu fees to be leveraged to produce more units than would have been built through onsite construction. 
approach to inclusionary housing that relies on innovative development, public private partnerships, subcontracting, leveraging of resources, and comprehensive inclusionary requirements for all development. Since adopting the ordinance in 2000, Mammoth Lakes has produced or has in the development pipeline approximately 200 affordable housing units as a result of its IH program.

Mammoth Lakes is, in many ways, unique when compared to most jurisdictions in California. However, its experience offers important lessons for other cities and counties that are considering adoption of an $\mathrm{IH}$ or updating an existing program. Much of what has been accomplished in Mammoth Lakes can, to some degree, be transplanted to very different communities, large or small.

\section{Comprehensive Ordinance as a Platform for Innovation}

Innovation begins in Mammoth Lakes with the Affordable Housing Mitigation ordinance, itself. Early on, in the drafting of the ordinance, it was realized that development, whether it be various forms of residential, hospitality, or commercial, creates jobs for workers who then need housing they can afford. Due to its remote location, there is no town or developed area outside Mammoth Lakes that can serve as the low-cost bedroom community for the area's workforce. Treating the problem as comprehensive, the ordinance was drafted to equitably share the responsibility of creating workforce housing among various kinds of development.

\section{Affordable Housing Overlay Zones}

A complementary element of this comprehensive approach not tied directly to the mitigation regulations has been the establishment of Affordable Housing Overlay Zones. Within these zones, all units must be affordable to households with incomes ranging from very low-income up to moderate-income. Overlay zones are incentive-rich targeted development areas with higher densities, fee waivers, relaxed parking standards and other zoning concessions available. Currently, this code provision is applied to one 25- acre parcel in the town.

\section{Proportionate Affordable Housing Contributions}

The driving principle of the Affordable Housing Mitigation ordinance is that development must house the workforce it generates. Formulas that match the form of development with job generation determine the number of Full Time Employee Equivalent (FTEE) housing units that must be produced. Because of extremely high housing costs, the ordinance targets income levels ranging from 80 to $200 \%$ of the area median income. Small developments where it is not feasible to produce the units - such as individual custom homes - are permitted to pay an inlieu fee. Based on the FTEE unit requirements, an individual Housing Mitigation Development Plan (HMDP) for each project must be produced and approved by the Planning Commission for each development to proceed. 


\begin{tabular}{|c|c|c|}
\hline \multicolumn{3}{|c|}{ Mammoth Lakes: Affordable Housing Mitigation Requirements } \\
\hline $\begin{array}{l}\text { 1. Visitor Accommodations. (Includes } \\
\text { hotels, multiple-family } \\
\text { condominiums in all zones other } \\
\text { than RMF-1 or A-H, fractional } \\
\text { ownerships, and all other visitor } \\
\text { accommodations). } \\
\end{array}$ & \multicolumn{2}{|c|}{.225 FTEE per sleeping area } \\
\hline $\begin{array}{l}\text { 2. } \begin{array}{l}\text { Commercial including } \\
\text { retail/office/restaurant, etc. }\end{array} \\
\end{array}$ & \multicolumn{2}{|c|}{.42 FTEE per 1,000 sq. ft. } \\
\hline 3. Industrial/service commercial. & \multicolumn{2}{|c|}{.11 FTEE per 1,000 sq. ft. } \\
\hline $\begin{array}{l}\text { 4. Multiple-family condominiums in the } \\
\text { RMF-1 or A-H zone (no transient } \\
\text { rental). }\end{array}$ & \multicolumn{2}{|c|}{.00012 FTEE per sq. ft. } \\
\hline \multirow{2}{*}{$\begin{array}{l}\text { 5. Single-family residences not } \\
\text { included. }\end{array}$} & \multicolumn{2}{|c|}{ For the portion of the building area from: } \\
\hline & $\begin{array}{l}0-2,000 \text { s.f., } \\
2001-4,000 \text { s.f., } \\
4001-6,000 \text { s.f. } \\
6,001-8,000 \text { s.f. } \\
8001 \text { s.f. and up }\end{array}$ & $\begin{array}{l}.00006 \text { FTEE per s.f. } \\
.00009 \text { FTEE per s.f. } \\
.00012 \text { FTEE per s.f. } \\
.00015 \text { FTEE per s.f. } \\
.00018 \text { FTEE per s.f. }\end{array}$ \\
\hline $\begin{array}{l}\text { 6. } \\
\text { Rental apartments and deed-/rent- } \\
\text { restricted housing. }\end{array}$ & \multicolumn{2}{|l|}{0 FTEE } \\
\hline 7. Uses not listed. & \multicolumn{2}{|c|}{$\begin{array}{l}\text { To be determined by Community } \\
\text { Development Director based upon } \\
\text { comparisons with like businesses. }\end{array}$} \\
\hline
\end{tabular}

Mammoth Lakes' inclusionary housing program requires that the FTEE units be developed onsite except where the location is unsuitable or alternatives would better achieve affordable workforce housing goals. In such cases, the ordinance allows for alternative HMDPs that can include construction on a different location, land dedications, housing acquisition and rehabilitation, or in-lieu fees. Alternative HMDPs, however, must be approved by the planning commission.

\section{Ordinance Flexibility and Entrepreneurship}

Since much of the development is luxury condos, commercial, retail, or hospitality industry construction, many of these developers would prefer not to construct the housing themselves. Such developments are often upscale ventures that promise very high profit margins. Affordable housing is not the expertise of such developers and they are concerned that building FTEE units will create delays. Many prefer to satisfy their affordable housing requirements with more expeditious alternatives.

It is at this juncture that the Town of Mammoth Lakes can become quite innovative and proactive. It is not unusual for the Town to open negotiations with developers and propose winwin alternatives to on-site construction. The Town has been able to reach agreements on alternative HMDPs, such as land dedications or in-lieu fees that result in more housing being produced than if the developer met the obligation through on-site construction. The benefit for the developer is the ability to quickly and more easily satisfy the workforce housing obligation. For these alternative HMDPs to work, it is essential that a local developer is in place to utilize the resources (e.g., fees and land they provide). 


\section{Local Capacity-Development and Partnerships}

Early on, Mammoth Lakes recognized that the Affordable Housing Mitigation ordinance can only be a partial solution to the shortage of affordable workforce housing. Much of the local workforce was employed by employers who were already in place before the ordinance and, therefore, had no obligation to contribute to the housing of their employees. Many of these workers were low- and moderate-income and were often living in overcrowded, substandard, and/or cost-burdened housing situations. Housing to meet those needs would have to be produced outside the Affordable Housing Mitigation ordinance.

It was also understood that the Affordable Housing Mitigation Ordinance itself would still require a build-up of local capacity. Even under the best of circumstances, not all developers would be able to construct workforce housing on-site. In some circumstances the location of development or the nature of the use (e.g., industrial) would be unsuitable for on-site construction and some alternative would be required. Even when on-site construction occurred, there would still be a need to administer and monitor the housing and enforce compliance.

This process gave birth to a unique nonprofit - Mammoth Lakes Housing, Inc. (MLH). MLH was established in 2003 through seed money amounting to approximately $\$ 200,000$ from the Town, a larger resort developer, and other sources. Its role was intended to administer and develop affordable housing programs and projects. Of particular importance in the establishment of MLH was the selection of an executive director with entrepreneurial skills and aptitude. MLH, although a private nonprofit, has a Town representative on the board of directors and works closely with the Town and Planning Commission in the planning and administration of the inclusionary ordinance. To date, MLH has leveraged that original $\$ 200,000$ investment into over $\$ 20,000,000$ in funds towards affordable and workforce housing in the community.

\section{Funding Support}

The Town of Mammoth Lakes also understood that a dedicated revenue source would be needed to provide a secure funding base. Consequently, in March of 2002, voters passed a ballot measure to increase the Transient Occupancy Tax (TOT) to 12 percent. In a complimentary move, the Town Council made the political commitment to dedicate one percent of the 12 percent TOT to the Workforce Housing Fund.

\section{Contracting Complements Capacity Development and Program Implementation}

Contracting out important functions of the Affordable Housing Mitigation Program to MLH has been an important component of local capacity development. Administratively, one of MLH's most important roles is to review alternative HMDPs as a consultant for the Planning Commission. Another crucial role is marketing, qualifying, and placing eligible households in the rental and ownership units created by the Affordable Housing Mitigation ordinance. MLH also monitors this housing for compliance, oversees sales of ownership units, and works to resolve various problems that may arise with these units. It is when an alternative HMDP is put into action, however, that MLH plays its most important role.

\section{Innovation in Action: Aspen Village at Mammoth Creek}

The Aspen Village at Mammoth Creek project illustrates the importance of a local developer and its place in the Affordable Housing Mitigation program in Mammoth Lakes. Aspen Village 
originated out of a luxury condominium project's requirement to provide workforce housing under the ordinance. The condominium project was to be developed in phases and the housing mitigation, nearly 80 three-bedroom, affordable rental units would also have to be phased in. The Town and MLH decided a well planned, single phase affordable development pioneered by MLH would provide more affordable units to the community more expeditiously, if the land were dedicated in-lieu. When approached by the Town staff and MLH, the developer was quite receptive to an alternative proposal that allowed it to dedicate 4.41 acres in return for mitigation credits applicable to their condominium project.

The developer received credit for approximately half of the units it would have otherwise developed. MLH, working with the Town, took the property and built twice as many units as the developer was given credit for. The developer received credit for 38 housing units and MLH developed a workforce neighborhood comprised of 72 units, both rental and purchasable, serving a broad range of household incomes. The Town and MLH received state HOME funds to provide gap financing for the rental portion of the project and utilized the Workforce Housing Fund and state homebuyer's assistance funds to subsidize the purchasable units. In the spirit of this innovative approach, MLH also used an innovative construction strategy of modular components for some of the units to further maximize the use of resources. As a result of Mammoth Lakes' entrepreneurial approach, 48 affordable lower-income rental units and 24 condominium units serving low- to upper moderate-income households were produced.

\section{Lessons from Mammoth Lakes}

Mammoth Lakes illustrates how jurisdictions can become proactive participants in the implementation of inclusionary housing. This strategy has proven successful because of a conscious strategy that addressed the housing problem comprehensively and proactively. Some of the key principles of this strategy are:

1. Develop a comprehensive workforce/affordable housing strategy

2. Engage the development community in creation of the strategy

3. Recognize inclusionary housing is just one tool to meet these housing needs

4. Require all development to make a proportionate contribution to affordable housing needs

5. Design an ordinance with strong production requirements

6. Build in ordinance flexibility on how productions goals are met

7. Utilize flexibility to leverage more units

8. Build local entrepreneurial development and administrative capacity

9. Involve the jurisdiction as a proactive and creative implementer of the ordinance

10. Commit a revenue source to support the program

\section{Patterson: Challenges of Fee-Based Inclusionary Housing}

As communities throughout California debate what type of inclusionary program best meets their needs, Patterson's experiences highlight the challenges of a fee-based program. Nearly eleven years after adopting its inclusionary program in 1995, few affordable homes had been built in the city. As a result, Patterson is in the process of overhauling its policy and moving away from a fee-based program to ensure that in the next decade affordable homes get built. 
Patterson is a small, but rapidly growing agriculture community in the heart of the Central Valley. Since 2000 , the number of housing units has increased by $35 \%$. As development took off, the City implemented an inclusionary program that requires developers to build $5 \%$ of new residential units affordable to moderateincome households and 5\% to be affordable to lowincome and very-low income households. The program was

Population: 16,000

Location: Stanislaus County

Year Inclusionary Adopted: 1995

Inclusionary Requirement: 5\% affordable to moderate- and $5 \%$ affordable to low- or very low-income

Alternatives to Construction: In-lieu fee

Amount of In-Lieu Fee: $\$ 20,946$ per market-rate unit (effective May 8, 2006)

Number of Affordable Units Produced by IH: 13 singlefamily homes; 24 senior apartments (construction to be completed December 2006)

Lesson Learned: Low in-lieu fees place too much burden on City

straightforward: build the units or pay an in-lieu fee. Not surprisingly, nearly every developer opted to pay the in-lieu fee, which was initially set at $\$ 319.00$ per new residential housing unit and then raised to $\$ 734.00$ in 2001.

The City estimates that 13 single-family homes built about 8 years ago are the only affordable units produced through the program to date. Outside of the program, 138 affordable singlefamily homes have been built since 1995. All of these homes were constructed by Self Help Enterprises, a Visalia-based nonprofit housing developer.

With such low in-lieu fees, Patterson's program took years to raise sufficient funds. To date, the City has collected $\$ 1.4$ million through its inclusionary program and, this year, the City just approved the first expenditure of these funds towards an affordable senior rental property. The development is a joint venture between the County of Stanislaus Housing Authority and a nonprofit. The City provided a $\$ 900,000$ loan from the Affordable Housing In-lieu Fee Fund for the 24-unit project.

Patterson's low in-lieu fees left the City with a second problem. Not only did it take years to accrue sufficient funds, but the City was left with the job of developing the affordable housing. But, as planning staff point out, the City is not in the business of building housing and had very little staff time to commit to the program. It was not until October of 2004 when the City hired a Housing Program Coordinator that significant staff time was committed to putting the Affordable Housing In-Lieu Fee Fund to use.

Patterson is about to embark on another explosion of growth, as a master development of over 3,100 housing units is in the pipeline. The City understands that its fee-based inclusionary program will not get homes built and has begun the process of revising the program and strengthening its tools to provide affordable housing.

In March 2006, the City Council unanimously voted to raise Patterson's in-lieu fee from $\$ 734.00$ per new residential unit to $\$ 20,946^{7}$ per unit, effective May 8,2006 . The City anticipates that

\footnotetext{
${ }^{7}$ Patterson commissioned a fee justification study to assist in determining the new affordable housing in-lieu fee. The study determined the in-lieu fee should be based on a "gap analysis," which is the difference between the maximum housing prices that are affordable to a lower-income household and the cost of a market-rate unit. The study calculated what the "gap" is for moderate-, low-, and very low-income households. It then reviewed Patterson's construction goals
}

ACEO AÑO II, núm.5, octubre 2007 | INCLUSIONARY HOUSING IN SMALL TOWNS AND RURAL PLACES: THE 
with such a large increase in fees more, if not all, developers will opt to build the affordable units and the municipality will no longer be in the position of ensuring the affordable units are built. It is also rewriting its inclusionary policy to address such issues as length of affordability and the setting of sales prices and rents.

Patterson anticipates that it will make significant strides in providing affordable housing in the second decade of its $\mathrm{IH}$ program. Beyond the inclusionary ordinance, the City is employing other tools to facilitate affordable housing production. In its 2004 General Plan update, the City adopted a policy that authorizes it to approve land annexations for residential developments if the project will result in a "significant public benefit." A significant public benefit includes: 1) a significant number of new jobs; 2) a public facility; or 3) the provision of affordable housing beyond what is required by the City's other affordable housing requirements.

In other words, if a residential project will make more than 10 percent of the housing units affordable, the City may approve a land annexation. The City implemented this policy when approving a 3,100-unit master development and, as a result, $20 \%$ of the housing units will be affordable to moderate-, low- and very low-income families.

\section{Lessons from Patterson}

Patterson's inclusionary program demonstrates that low fees will not allow a city to raise sufficient funds quickly and, even if funds are sufficient, the city is forced into the role of developer. This is a particularly daunting job for smaller cities that do not have the staff time to commit or the experience to build housing and where an affordable housing developer is not at the ready with a project to produce the units.

\section{Ripon: Strong Commitment Gets Homes Built}

The City of Ripon seems to be accomplishing something many communities struggle with: integrated neighborhoods with homeownership opportunities for families with a wide range of incomes. Ripon has some of the most expensive home prices in the San Joaquin Valley, but also has the region's most productive inclusionary housing program. Stressing on-site construction and economic integration, Ripon has produced 113 single-family affordable homes in less than 5 years. Many of these homes reside in high-end neighborhoods and, in some cases, sit side-by-side with $\$ 800,000$ to $\$ 1.4$ million homes.

Most surprisingly, over $60 \%$ of the homes produced through the city's program are affordable to those most difficult to assist - low- and very low-income households. While a number of factors

Population: 13,000

Location: San Joaquin County

Year Inclusionary Adopted: 2001

Inclusionary Requirement: 3\% affordable at very-low, 3\%

at low-, $3 \%$ at moderate-income

Length of Affordability: 45-55 years

Alternatives: In-lieu fees for small projects, off-site construction, joint ventures

Number of Affordable Units Produced: 113 single-family homes affordable to moderate-, low- and very low-income households

Lessons Learned: Specify income-targeting; monitor results and revise when necessary

for housing units affordable to these income levels and estimated the total subsidy needed to achieve this goal. Finally, the study determined the in-lieu fee by dividing the total subsidy needed by the number of housing units allowed for in the General Plan. The study is available on Patterson's website: http://www.ci.patterson.ca.us/Default.aspx?pi=79\&ni=100 
contribute to Ripon's success, the most important factor has been the City leadership's strong support of the policy and its willingness to closely monitor the outcomes and continually revise the program to ensure it is meeting the objective of providing affordable housing. The City has made four major amendments to the program since its 2001 adoption.

As with most small cities in the San Joaquin Valley, Ripon is best known for its predominant agricultural crop. It may be surprising to learn that the current range of sales prices for new homes in the Almond Capital of the World is around $\$ 500,000$ up to more than $\$ 1$ million. Its high home prices can likely be attributed to the fact it is located in California's fastest growing region, its reputation for having good schools, and its slow-growth policy. Ripon's inclusionary program is ensuring that at least some homes remain within reach of lower-income households.

\section{An overview of Ripon's Inclusionary Requirements}

The City Council's commitment to providing affordable housing emerged in 1998 when it began requiring that new developments include affordable units to attain approval. An inclusionary program was formally implemented in 2001 with the passage of Ripon's Below Market Rate Housing Program (BMR) ordinance. The ordinance applies to all new residential development projects and requires developers to provide $3 \%$ of the housing affordable to very low-income households, $3 \%$ at low and 3\% moderate. To ensure that the affordable units are built around the same time as the market-rate homes, the City issues the building permits for the market-rate and affordable units in stages. A developer only receives building permits for a portion of the total market-rate units and, then, must construct so many of the affordable units before the next round of market-rate building permits will be issued. Ownership units must remain affordable for 45 years and rental units for 55 years.

Citing economic integration as one of the goals of its inclusionary program, Ripon requires developers to build the affordable units on-site and disperse them throughout the project. The ordinance does state off-site construction may be appropriate at times and allows developers to partner with another developer to build the units, but to date all affordable homes have been built on-site. Ripon does allow small projects, those with fewer than 10 units, to pay in-lieu fees rather than build units. Developers may also pay fees in-lieu of building the very low-income units; however, the fees are substantial. The current in-lieu fee per is $\$ 120,000$ per required unit and equals approximately $25 \%$ of the median home sales price.

\section{Strong Leadership Leads to Success}

Ripon's impressive production numbers and levels of affordability can be attributed to the City leadership and staff's strong commitment to the program. As is the case with all new policies, it took a few changes to the program to achieve the results the City wanted. The City has made four major changes to the program, which addresses concerns about income-targeting, sales prices, and equity, and provides developers with another option to meet their inclusionary requirement.

\section{Amendment 1: Specify Income-Targeting}

The initial policy required $10 \%$ of new homes to be affordable, but allowed developers to choose what level of affordability they would build for ranging from moderate- to very low-income. The City quickly found that all the affordable units were being built at the moderate level and, as written, the policy would not result in ownership or rental opportunities for low- and very lowincome households. So, the City amended the ordnance to specify $3 \%$ at moderate, $3 \%$ t at low, and $3 \%$ at very low. 


\section{Amendment 2: Establish Sales Prices and Rents}

Once the first round of affordable homes was completed and being sold, the City became concerned with the sales prices and down payments being required on the units. The initial ordinance specified how affordable monthly housing costs and rents must be calculated, but allowed the developer to do the calculations and set the prices. The City found that the home sale prices were too high and low-income buyers were being required to put down as much as $\$ 70,000$, pushing the homes out of reach for many the ordinance intended to assist. Ripon amended the ordinance to state that the City will now calculate and establish the sales prices.

\section{Amendment 3: Relax Home Resale Requirements}

The third amendment to the ordinance also addresses the needs of moderate-, low- and very low-income homebuyers. Ownership units have an affordability term of 45 years. Initially, if a buyer of an affordable home sold the home before the 45-year term, the home's sales price was restricted and had to be sold to a moderate-, low- or very low-income household. The City felt this placed too much burden on homebuyers and did not allow them to fully reap the benefits of homeownership. As a result, the policy has been amended to allow buyers of the affordable homes to sell the units at market price, but then pay back the subsidy amount to the City.

The subsidy equals the difference between the market value of the home at the time it was sold to the owner and the actual purchase price the owner paid for the home. If an owner sells the affordable unit within 5 years of the purchase, he must pay the full subsidy amount and any accrued interest. After 5 years, the City begins to forgive the subsidy so that by the end of the 45-year affordability term an owner will keep all the equity. It is the City's intent that funds collected through this new policy will then be used to build additional affordable units. The ordinance also authorizes the City to purchase any owner-occupied affordable unit for its market value when an owner plans to sell, giving the City an opportunity to then sell the home to another lower-income household.

\section{Amendment 4: Allow More Developer Options via Second Dwelling Units}

Lastly, Ripon has recently decided to allow developers to fulfill their inclusionary requirements in part by building second units, commonly called "granny flats." If a developer opts to do this, he must build two granny flats for every one affordable unit required. This option can only fulfill the very low-income requirement and one-half of the low-income requirements. Since its inception in 2005, two developers have opted to construct second dwelling units providing 12 units instead of 6 . This new amendment benefits both the City and developers, as it results in more affordable units and provides developers an additional option.

Ripon's impressive production numbers and affordability levels are directly tied to the City's close monitoring of the program and willingness to revise its policies. As initially written, the program may have resulted in fewer affordable homes and homes priced only within the payment ability of moderate-income households. The production numbers discussed below suggest Ripon's revisions are working.

Since 2000, approximately 1,200 new housing units have been built in Ripon, which has a General Plan policy limiting growth to $3-6 \%$ per year. The City's goal is for at least $10 \%$ of new residential development to be affordable, and it has come close to reaching this objective. One hundred thirteen affordable single-family homes have been built in Ripon since 2001, and the City has 100 more affordable units, both rental and ownership, in the pipeline.

More than $60 \%$ of Ripon's inclusionary single-family homes are affordable to low- and very lowincome households, an impressive outcome. Opponents of inclusionary housing often claim that building at these levels is impossible and, if forced to, developers will pack up and build elsewhere. 


\begin{tabular}{|c|c|}
\hline \multicolumn{2}{|c|}{ Inclusionary homes built since 2001 } \\
\hline Income Level & Number of Units \\
\hline Very Low & 16 \\
\hline Low & 57 \\
\hline Moderate & 40 \\
\hline
\end{tabular}

This has not been the case in Ripon, where to date all developers have fulfilled their inclusionary requirement by building the homes onsite. Ripon has collected only one in-lieu fee of $\$ 98,000$.

To help developers meet their inclusionary requirements, the City allows some flexibility of design standards for the affordable units. While affordable units must be comparable in exterior appearance and overall quality and have the average number of bedrooms of the market-rate units, the units can be smaller and have different interior features. In one recent development the affordable homes were 1,500 square feet while the market-rate homes were 2,400 square feet.

Developers may also build a variety of housing types to fulfill their affordable requirements. To date, developers have constructed affordable single-family detached homes, duets, townhouses, and second dwelling units.

The City does not offer financial assistance to developers to off-set the cost of the $10 \%$ obligation to provide affordable homes ${ }^{8}$, and believes that developers are able to both make a profit and fulfill their inclusionary requirements. Based on their knowledge of building costs, the City estimates that developers make a profit on homes sold to moderate-income households, make a small profit or break even on homes reserved for low-income households, and lose money on houses sold to very low-income households. At the same time, profits from the market-rate units in the development more than adequately off-set the costs of the $\mathrm{IH}$ units.

Ripon's experiences suggest that it is difficult to argue that developers are losing money by complying with inclusionary requirements. Some developers already consider Ripon to be one of the most expensive areas in the region to build, but are eager to do business there. The added expenses are recouped in the market-driven home prices.

\section{Lessons from Ripon}

For a small city, Ripon's inclusionary policy has yielded impressive results. Over the last 5 years, the City's policy has reached its target of $10 \%$ of new residential development being affordable to lower-income residents. This is not to say that all of the housing needs in Ripon have been met. Affordable rental housing is a gap the City needs to address. The majority of development in Ripon consists of single-family homes, but two projects currently under construction will provide 21 affordable apartments for seniors and 18 other apartments for lowincome households.

Ripon offers insight into the conditions necessary to achieve affordable homeownership at deep income levels. The high cost of housing helps developers meet their requirements and continue to profit, but most importantly the program's success should be attributed to strong support from the City's leadership. This support began in 1998 with project-by-project negotiations and was

\footnotetext{
${ }^{8}$ Ripon does provide financial assistance to developers who chose to build at least $20 \%$ of the units as affordable. The City will subsidize the additional $10 \%$ To date, three development projects have included an additional $10 \%$ and Ripon has assisted with a total of $\$ 1.6$ million.
} 
then formalized with the adoption of the BMR ordinance. The leadership is also evident today in the City's willingness to closely monitor and revise its program.

Winters: Flexibility and Partnerships

As one of the smallest cities in California with an inclusionary program, Winters offers insight into the unique challenges facing small jurisdictions. While the City has steadily moved towards its goal of $15 \%$ of new residential development being affordable, it has also struggled to find the most effective inclusionary tools. Today, a decade after implementing its program, the City is prioritizing on-site construction of homes and moving away from in-lieu fees and land dedications.

At the same time, Winters is continuing to utilize two tools it has found to be effective: flexibility and partnerships. To date, more than 100 affordable single- family homes have been built, and an additional 100 affordable units are in the pipeline.

\section{Quick Facts}

Population: 6,979

Location: Yolo County

Year Inclusionary Adopted: 1994

Inclusionary Requirement: $15 \%$ affordable: $6 \%$ at verylow and $9 \%$ for low- and moderate-income

Length of Affordability: 55 years

Alternatives to Construction: In-lieu fees, land dedications, partnerships with nonprofit developers

Number of Affordable Units Produced: 106 single-family homes affordable to moderate-, low -and very low-income households

Lessons Learned: In-lieu fees and land dedications place large burden on small city; work best if linked to a specific project

\section{Overview of Winters' Inclusionary Program}

Winters' IH program, which was implemented in 1994, requires projects of five or more units to make $6 \%$ of the homes affordable to very low-income households and $9 \%$ affordable to lowand moderate-income households. Units must remain affordable for 55 years. The City's ordinance allows developers to fulfill their inclusionary requirement in a number of ways, including direct construction of units by the developer, land dedication, payment of in-lieu fees, and joint ventures with nonprofit housing developers, all at the discretion of the City. However, the ordinance does state that "[t]he preferred action is construction of housing as compared to payment of in-lieu fees." It also states that in-lieu fees will only be permitted when on-site construction and dedication of land are found infeasible or if combined with one of these options.

The 106 affordable homes built through Winter's inclusionary program demonstrate the effectiveness of flexibility and partnerships. Seventy-six of the affordable units were developed through Mercy Housing California's sweat-equity program ${ }^{9}-$ a partnership between the marketrate developer, a nonprofit developer, and the City. The market-rate developer fulfilled its inclusionary requirement by selling the 76 parcels to Mercy Housing California (Mercy). Mercy and the participating families then built the homes, which sold at prices affordable to these low-

\footnotetext{
${ }^{9}$ Sweat equity is a program in which low and very-low income families are able to purchase their first home by contributing labor or "sweat equity" in place of a down payment. Families must commit to around 40 hours of labor per week for approximately 10-12 months. In exchange, they are able to purchase the home at an affordable price without a down payment and receive a low-interest mortgage (as low as $1 \%$ in rural areas eligible to receive USDA Rural Housing Service loans) from the federal government.
} 
and very low-income residents. Upon completion of the project, the City provided 12 first-time homebuyer loans.

The remaining 30 affordable homes were a partnership between the City and two for-profit developers. The homes are small-lot, single-family houses that were sold to moderate-, lowand very low income- families. The developer of Carter Ranch, a 140-unit market-rate subdivision, conveyed the property to Sacramento Pacific Development (SPD), a for-profit developer to build the affordable project. The project received a density bonus and the City allowed reduced standards for lot sizes, setbacks, and parking. Additionally, the City deferred impact fees for some of the units and provided first-time homebuyer loans for all of the low- and very low-income buyers.

\section{Challenges of Land Dedication and In-lieu Fees}

Winter's openness to creative ways of meeting its $15 \%$ affordability goal and its willingness to commit resources, such as first-time homebuyer assistance, were instrumental in both Mercy's sweat- equity and the SPD project. These projects also suggest that land dedication and/or land sales, as demonstrated by the Mercy and SPD projects, can be an effective inclusionary tool. A closer look, though, also reveals the challenges of land dedications for small cities like Winters.

Prior to 2000, the developer of Carter Ranch dedicated approximately three acres of "raw land" to the City to meets its inclusionary obligation. The City explored ways of developing this land, but quickly learned that it did want to be in the role of developer. Issues of prevailing wage, the fact that the land was not ready for construction, and the City's lack of experience in developing housing, led it to conclude that it would not be able to build affordable homes on the parcel. The City then worked with the Carter Ranch developer to find a third party that might be able to build on the parcel, and deeded the land back to the developer who in turn conveyed it to SPD. This experience led the City to conclude that land dedications will only work if a third party is available to develop the land.

To date, no developer has fulfilled its inclusionary requirement by building affordable units onsite. The City has allowed developers to utilize the alternatives to construction and a handful opted to pay in-lieu fees. However, Winters has found that in-lieu fees present two main challenges for small jurisdictions. First, like land dedications, it puts the City in the role of developer, which is especially difficult for a small jurisdiction with limited staffing and resources. Secondly, the fees quickly lose value as construction costs continue to rise.

Between 1994 and early 2006, the City collected less than $\$ 100,000$ in in-lieu fees. Two developers of small projects paid fees as low as $\$ 7,000$ to $\$ 9,000$ per required inclusionary unit. The City has not been able to turn the small amount of fees into affordable homes. It is now reviewing its in-lieu fee provisions and proactively encouraging developers to fulfill their inclusionary requirements by directly building the affordable units on-site.

A review of pipeline developments confirms Winters' new approach of prioritizing on-site construction. Winters Highlands, which is pending final map approval, is a 443-unit development that will include 66 units of affordable housing on-site. Callahan Estates a 120-unit singlefamily development awaiting final map approval will yield 18 affordable on-site units and Hudson-Ogando a 72-unit single-family development also pending final map approval will result in 11 affordable units on-site. All of these developments will include homes affordable to very low-, low- and moderate-income households.

At the same time, the City remains flexible and interested in promoting partnerships with nonprofit housing developers. Two pending developments, Creekside Estates and Winters II 
Apartments, illustrate how the City is merging these ideals with its new approach of prioritizing on-site construction.

Creekside Estates is a proposed development of 40 high-end single-family homes. Under the City's inclusionary ordinance, the developer is responsible for providing three very low-income units, two low-income units, and one moderate-income unit. The City has approved a plan for the developer to build four of the units on-site and to pay in-lieu fees for the remaining two units. However, the in-lieu fees are different from previous fees the City has approved in two important ways. First, the developer will pay $\$ 200,000$ in fees, a significant increase in past fee levels. Second, the fees will immediately be used to subsidize the development of a 34-unit multifamily affordable project, the Winters II Apartments, ensuring the funds do not linger or lose value.

The Winters II Apartments is being developed by a local nonprofit, Community Housing Opportunities Corporation (CHOC), which has developed and operated affordable housing in the region for decades. The developer of Creekside Estates contacted $\mathrm{CHOC}$ in the initial planning stages about collaborating to fulfill his very low-income unit requirement. While cautious about allowing market-rate developers to pay in-lieu fees, the City approved this developer's proposal to build some units and pay fees for the rest because of the readiness of $\mathrm{CHOC}$ to move forward with construction of additional affordable units. The $\$ 200,000$ subsidy, combined with the City's other contributions to the project - loans and grants of redevelopment funds totally $\$ 1.6$ million, a $\$ 2.8$ million loan through the HOME program, and leasing of the land - and other non-local funds assembled by $\mathrm{CHOC}$, will ensure that the units get built.

\section{Lessons from Winters}

Smaller communities around California can learn several lessons from Winters' decade of experience. Allowing developers to pay fees and dedicate land to fulfill their inclusionary requirement may overburden a small community that is not equipped to develop units. As a result, smaller jurisdictions may want take Winters' approach of prioritizing on-site construction.

At the same time, remaining flexible allows a locality to approve in-lieu fees or land dedications when the conditions are appropriate. Winters' experiences suggest that fees should be substantial and linked to a specific project that is underway. If a fee sits in a fund waiting to be used it loses value and the jurisdiction is burdened with the job of spending the money. Second, a third party, such as an affordable housing developer must be involved, so that the small jurisdiction is not overwhelmed with the role of housing developer.

\section{Why do Small Towns and Rural Places Adopt Inclusionary Housing?}

Logic would suggest that small towns and rural places, given historical and cultural predilections, would be unlikely to adopt government policies that dictate what private developers and landowners can build. After all, many rural residents treasure their independence and are deeply suspicious of anything that originates from government, especially anything that impinges on private property rights.

To ascertain exactly why jurisdictions as these adopt inclusionary housing one would need to conduct more extensive interviews and examinations of the public record than is the scope of this research. However, certain conclusions can be drawn from direct experience with the design and adoption processes in some of these communities, as well as an examination of the stated reasons and findings that often justify these policies in ordinances and local housing plans.

First, jurisdictions adopt IH because they need to do something under State law to meet their fair share of the regional need for affordable housing. Every 5 years, each California city and 
county is assigned a number of units by income band (e.g., very low-income, low-income, moderate-income) that represents its portion of the region's housing need based on existing demands and projections of new household formation. The numbers are calculated and allocated by the regional Council of Government (COG) or, in the case of rural communities not served by a COG, the California Department of Housing and Community Development. Noncompliance can result in scoring disadvantages in State funding programs, as well as court sanctions. In several jurisdictions, lawsuits or the threat of lawsuits have resulted in jurisdictions adopting $\mathrm{IH}$ programs either preemptively or in response to a court settlement. ${ }^{10}$

Second, the great majority of small jurisdictions that adopt inclusionary housing are facing significant population growth pressures. During the last two decades, the direction of growth has been away from the crowded and expensive coastal cities to the interior and more rural parts of the state where housing and land costs are cheaper. The influx of "equity immigrants", "super-commuters", second-home buyers, and retirees, combined with natural growth, has exerted enormous pressure on existing housing supplies. The private market, left alone, is not producing the new housing needed to accommodate local workers earning local wages - in other words, workforce housing for school teachers, public safety employees, nurses, service employees, and other critical workers who must commute long distances to their jobs or live in squalid and overcrowded conditions. Instead, new housing is being built and priced to appeal to higher-income newcomers rather than long-time residents and their children. For the sake of economic sustainability and generational succession, jurisdictions are realizing they must act now to affect the character and direction of growth.

In addition, small-town and rural housing markets are isolated and limited. Unlike cities in large metropolitan areas where there is typically a diverse housing stock and range of prices, residents of smaller jurisdictions must satisfy their housing needs within a narrow spectrum of choices and lower-income households are even more restricted. Often, rental housing vacancies are extremely low, if rental housing exists at all. Starter homes affordable for purchase by young couples may not exist or be severely substandard. The nearest housing alternatives may be 30 miles away in the next city. Local businesses are particularly attuned to this reality and have championed inclusionary strategies.

Third, despite perceptions to the contrary, land is a scarce resource in many small towns and rural places. The urbanized areas of small cities and counties are virtual islands surrounded by agricultural preserves, wetlands, natural habitats, federal, state, and Indian land, watersheds, and topographical features that limit and prevent residential development in volume. Lack of infrastructure - sewer, water, electricity, streets, and other public works - and services restrict where development can occur. The available buildable land may be held by a few large landowners or developers whose intent is to build up-scale housing that will yield the highest returns on investment. Therefore, if action is not taken now to dictate the kind of housing that can be built on the few remaining parcels, there will be no turning back the clock to a time when land was ample and housing affordable.

Fourth, the willingness of small jurisdictions, especially small cities, to overcome local politics and take bold and decisive action to adopt IH programs is often a derivative of scale. People know their neighbors. They directly feel the shortage of affordable housing. They know where the few remaining parcels of developable land are located. They know that the character of their communities is changing. And, they have access to their elected officials who work in the

\footnotetext{
${ }^{10}$ In the case of Folsom, California, see Settlement Agreement and Release of Claims in Ronald Hallfeldt v. See City of Folsom, et al., Case No. 01CS01149, April 2002. Folsom agreed to adopt an inclusionary housing ordinance pursuant to a suit brought by Legal Services of Northern California claiming that the City had not set aside adequate sites to meet its fair share of the regional housing need as required by State law and stated in the Housing Element of its General Plan. Settlement agreements also spurred adoption of inclusionary programs in the cities of Alameda (military base reuse), Benicia, Buellton, Corte Madera, Healdsburg, Los Altos, and Winters.
}

ACEO AÑO ||, núm.5, octubre 2007 | INCLUSIONARY HOUSING IN SMALL TOWNS AND RURAL PLACES: THE 
same work places, shop in the same stores, and send their kids to the same schools. Unlike large cities where these relationships are more impersonal and urban conditions more amorphous, one can really comprehend the nature of the housing problem and how an inclusionary program could benefit the community.

Finally, adoption of an IH program in smaller jurisdictions may be informed not only by the above considerations, but by a sober recognition that they have few other options to meet their affordable housing needs and State mandates. Most of these jurisdictions do not have redevelopment agencies. Where they do, the scale of redevelopment is low and, thus, the dollar amount of tax increments recaptured for reinvestment in affordable housing is low. Federal Community Development Block Grant and HOME Investment program dollars available to large cities and metropolitan counties on an entitlement basis must be sought from the State on a highly competitive basis. Staff to access other federal and State funds and operate affordable housing programs are limited in numbers and expertise. Nonprofit housing developers are spread thin and cannot work in all jurisdictions at once. Thus, the allure of an $\mathrm{IH}$ program that requires little in the way of public expenditure and shifts responsibility for affordable housing production to the private construction industry is a compelling alternative.

\section{Conclusion}

For over 30 years, inclusionary housing has been a tool for local governments across the country and in California to manage the character of residential growth and create inclusive communities.

Analysis of recent surveys, distillation of information from ordinances and policies, and case studies reveal that $\mathrm{IH}$ is working, albeit with great variation from jurisdiction to jurisdiction. Not only is it a strategy for large cities, suburbs, and metropolitan counties, but increasingly it is a strategy of choice for small towns and rural places that are experiencing growth pressures and decreasing ability of local residents to afford local housing. In small towns and rural tourist, resort, and retirement destinations, shortages of housing for teachers, fire fighters, policemen, nurses, tourism workers, and other service employees has aroused broad concern.

\section{Barriers to Design, Adoption, and Implementation}

Despite the impressive number and record of inclusionary housing programs in California, design, adoption, and implementation of these programs is complicated, contentious, and timeconsuming. As demonstrated by our case studies, small towns and rural places face many of the same barriers as larger communities, but also barriers that are unique to or more pervasive in smaller communities:

Strong political opposition. An analysis of the spatial location of existing inclusionary housing programs in California is revealing. Most programs are located in coastal counties. Many fewer can be found in the Central Valley and other interior parts of the state. This is no coincidence. While it is certainly true that coastal communities first experienced the housing affordability crisis, it is also true that the politics of the state are decidedly more conservative the farther one travels away from the coast. In small towns and rural places, ideological opposition to government regulation of land use and belief in the private market are strong. The building and real estate industries wield considerable influence, while grassroots movements of affordable housing advocates and low-income people are non-existent or weak.

Scarcity of developable land. Despite appearances to the contrary, many small towns and rural places lack developable land. Critical infrastructure, such as sewer, water, utilities, and roads, may be absent, difficult topography may preclude larger development, natural habitats, wetlands, forests, and agricultural land may be protected, and large holdings may be in federal, 
state, or tribal ownership. Limitations in the supply of land can prevent developers from building in volume.

Concerns about higher density. The old adage that the only thing people dislike more than sprawl is high density is especially true in small towns and rural places. The low-density, single-family detached profile of existing housing is the social and cultural norm and extremely difficult to overcome. Multi-unit, multi-story developments are uncommon. To the extent that inclusionary housing is smaller, more compact, and higher-density than conventional homes, concerns may emerge about congestion, urbanization, and the changing character of these communities.

Stereotypes about affordable housing. Negative images of affordable housing can be found in any size community because of associations with failed projects, inner city slums, crime, reduced property values, and in some cases racial and ethnic minorities. There is a perception that such housing only serves "welfare" cases and illegal immigrants, not the deserving poor. These stereotypes are especially deep in small towns and rural places. Fears about the importation of urban problems often accompany efforts to design and adopt inclusionary housing programs and other affordable housing strategies.

Lack of local capacity. Finally, the design, adoption, and implementation of an inclusionary housing program require sophisticated, durable, and dedicated leadership from a diverse group of local stakeholders - government officials, business people, labor unions, clergy, educators, public safety employees, and low-income advocates. Moreover, the administration of $\mathrm{IH}$ programs and long-term monitoring of compliance with affordability covenants can be laborintensive and requires expertise. This is especially so for homes that are sold to lower-income households and controlled by complicated equity-sharing arrangements. Oftentimes, small towns and rural places do not have the wherewithal to effectively design and adopt these programs, nor to ensure professional implementation and administration over the long-run.

\section{Ingredients for Success}

To achieve success, small towns and rural places must follow many of the same steps and incorporate many of the same elements as programs in larger communities. But, as mentioned above, these jurisdictions also face limitations and environments that are unique. Successful programs typically demonstrate the following characteristics:

Strong political commitment. Political champions are important in any community. However, in small towns and rural places where governance and politics can be deeply personal, courageous and proactive leadership is needed to overcome entrenched power and mobilize grassroots citizens to take a stand. In some tourist, resort, and retirement communities, the housing situation has reached such crisis proportions that the business community has begun to mobilize and call for a different residential land use pattern to sustain the local economy. Leadership from business and other sectors is also emerging in jurisdictions that have become bedroom communities and magnets for growth.

Customized design. Small towns and rural places must carefully evaluate their housing needs and housing market dynamics and design and adopt programs best calibrated to local conditions. For example, it may make sense to start off with a relatively modest affordability percentage requirement to overcome opposition. Given the relatively small scale of existing residential development, it would be impractical to establish a high development-size threshold to trigger the $\mathrm{IH}$ requirement, say 10 or more units, because developers will likely opt to build individual ranchettes, duplexes, four-plexes, and other small projects to avoid the requirement. 
Flexible design. Likewise, many of the most successful programs offer developers options, rather than a rigid "take-it-or-leave-it" or "one-size-fits-all" approach. Typically, this involves a negotiation and a menu of incentives to help offset the costs of producing the below-market-rate units. Such flexibility may include a reduced affordability percentage if the inclusionary units serve a lower-income population, density bonuses to permit additional market-rate units, design concessions, such as smaller streets, sidewalks, set-backs, and fewer parking stalls, and reduced or waived fees. Alternatives to on-site development by the developer may also be offered, including land dedications, credit transfers, and in-lieu fees.

Unattractive fee alternative. Some programs have fallen short of expectations because the inlieu fee alternative is more attractive to developers than building the units. In the City of Patterson, for example, the fee per unit wasn't remotely close to the cost of building a new unit. As a result, developers opted to pay the fee and no new units were generated. In small towns and rural places, direct development of the units by the private developer is most preferable because of the difficulty of marshalling sufficient fees to build the same number of units and the absence of affordable housing developers, such as local nonprofit organizations, and local staff at the ready to produce them.

Partnerships. In the absence of local government capacity, partnerships with regional or local nonprofit developers and others who can build and, in the case of rental housing, operate the affordable units are critical. Moreover, these organizations may provide consultation and be available to assist with long-term administration, monitoring, and oversight of the program.

Simple and sustainable administration. Finally, to overcome the capacity challenge, small towns and rural places must often depend on volunteers from the community to design and advocate for an IH program. To achieve political support and simplify administration, some jurisdictions have adopted streamlined programs that provide limited or no alternatives to onsite development by market-rate developers, the purpose being to eliminate the possibilities that the jurisdiction will be saddled with fees or land that will require it to act as a de facto developer. This must be carefully weighed against the benefits of a more flexible menu of incentives and alternatives. Out-sourcing the most complex and cumbersome components of program implementation to capable contractors, such as nonprofit organizations, is another option to relieve administrative staff and increase program effectiveness.

As inclusionary housing continues to expand into an increasing number of cities and counties, not only in California but the U.S., it is important to understand why so many smaller jurisdictions are adopting this strategy to address their affordable housing concerns. Is it because of state affordable housing mandates, lack of alternative means to achieve affordable housing goals, a unique sense of urgency and understanding of affordable housing needs, or concerns about urbanization and the changing character of these communities? Given the relatively high number of programs and more than 30 years' experience, a strong case can be made that $\mathrm{IH}$ to date has been, and continues to be, a largely suburban, small town, and rural phenomenon. More research is needed to fully comprehend the innovations and adaptations in IH design, adoption, and implementation within smaller jurisdictions. 


\section{References}

Abt Associates and Newport Partners. 2006. Inclusionary Housing 101. U.S. Department of Housing and Urban Development. Washington, D.C.

Anderson, Mary. 2003. Opening the Door to Inclusionary Housing: 2003 Condensed Edition. Business and Professional People in the Public Interest. Chicago, II.

Basolo, Victoria, and Calavita, Nico. 2004. Policy Claims with Weak Evidence: A Critique of the Reason Foundation Study on Inclusionary Housing Policy in the San Francisco Bay Area. San Diego State University and University of California, Irvine. San Diego and Irvine, CA.

Brunick, Nicolas. 2004. "Inclusionary Housing: Proven Success in Large Cities" in Zoning Practice, Issue 10, October 2004. American Planning Association. Chicago, II.

Brunick, Nicholas. 2004. The Impact of Inclusionary Zoning on Development. Business and Professional People for the Public Interest. Chicago, II.

Calavita, Nico. 2006. Inclusionary Housing in the U.S. and Europe. Paper delivered at $42^{\text {nd }}$ ISoCaRP Congress, Istanbul, Turkey.

California Coalition for Rural Housing. 1994. Creating Affordable Communities: Inclusionary Housing Programs in California. Sacramento, CA.

California Coalition for Rural Housing and Nonprofit Housing Association of Northern California. 2003. Inclusionary Housing in California: 30 Years of Innovation. Sacramento and San Francisco, CA.

Marcuse, Peter. 1986. "Housing Policy and the Myth of the Benevolent State" and "Afterword" in Critical Perspectives in Housing, pp. 248-263. Temple University Press, Philadelphia, PA.

National Housing Conference. 2004. Inclusionary Zoning: The California Experience. NHC Affordable Housing Policy Review, Volume 3, Issue 1, February 2004. Washington, D.C.

Nelson, Arthur, and Moody, Mitch. 2003. "Paying for Prosperity: Impact Fees and Job Growth" in Cities and Suburbs Reports. Brookings Institution, Washington, D.C.

Nonprofit Housing Association of Northern California, California Coalition for Rural Housing, San Diego Housing Federation, and Sacramento Housing Alliance. 2007. Affordable by Choice: Trends in California Inclusionary Housing Programs. San Francisco, CA.

Policy Link. 2003. Expanding Housing Opportunity in Washington, D.C.: The Case for Inclusionary Housing. Oakland, CA.

Policy Link and Pratt Institute Center for Community and Environmental Development. 2004. Increasing Housing Opportunity in New York City: The Case for Inclusionary Zoning. Oakland, CA, and New York City, NY.

Porter, Douglas. 2004. Inclusionary Zoning for Affordable Housing. Urban Land Institute. Washington, D.C.

Powell, Benjamin, and Stringham, Edward. 2004. Housing Supply and Affordability: Do Affordable Housing Mandates Work? Reason Foundation. Los Angeles, CA. 
Rosen, David. 2004. "Inclusionary Housing and Its Impacts on Housing and Land Markets" in Inclusionary Zoning: The California Experience. NHC Affordable Housing Policy Review, Volume 3, Issue 1, February 2004. National Housing Conference, Washington, D.C.

Rusk, David. 2005. "Reason Foundation reports against inclusionary zoning" in memo to Empower Hampton Roads. Washington, D.C. 
Architecture, City, and Environment

Arquitectura, Ciudad y Entorno 